\title{
The Problems in the Cultivation of College Students' National Defense Consciousness and Its Countermeasures
}

\author{
Haiyan Zuo
}

Weinan Normal University, Weinan, Shaanxi, 714099

Keywords: college students; national defense awareness; problem analysis

\begin{abstract}
National defense education is an important component of higher education, which carries out specific, universal, and defensive education activities for all citizens on a political, military, and economic basis according to certain national defense goals, according to certain theories, methods, and specific means. At this stage, our country is in a special period of social transformation, social stability has suffered a certain amount of impact, and national defense is the core force that safeguards China's national independence and territorial integrity. Therefore, it is of great significance to strengthen national defense education in colleges and universities. However, influenced by various factors, the national defense concept of Chinese college students has been seriously declining compared with decades ago. Many students lack a basic sense of national defense. Even some students do not realize the seriousness of the problem when they disclose state secrets. The national defense education in colleges and universities and the cultivation of college students' national defense awareness are urgently needed. This paper mainly analyzes the problems existing in the cultivation of the national defense awareness of Chinese college students and proposes specific solutions.
\end{abstract}

\section{Introduction}

College students are a vigorous and healthy group. They are not only young and creative, but also have a high level of overall scientific and cultural quality. They are themselves excellent sources of national defense reserve forces. Under the guidance of the idea of strengthening the military with science and technology, the use of electronic information technology and Internet technology in the military field has become more and more widespread, and the requirements for the quality and ability of military personnel have also become higher and higher. The college students have a strong overall quality and a high level of education. To train and train them, college students will become high-quality new military talents. If we further strengthen the national defense education for students, guide them to establish a strong sense of national defense, and possess the necessary national defense skills and related knowledge, they can be trained as potential military backup forces. If a war occurs, the team can immediately put in Go to the battle. Therefore, strengthening national defense education for college students during peacetime can make them more fully prepared for military skills, psychological quality, and physical fitness.

The new educational concept emphasizes quality education, emphasizing the improvement of students' comprehensive ability, cultivating the all-round and high-quality successors of socialism with Chinese characteristics, while national defense awareness is an important part of the overall quality of college students. In the process of receiving military training and national defense education, students can hone their will, improve their psychological and physiological capabilities, and promote their development through the organic integration of theory and practice, which can make up for school education better. The inadequacies of the development of students' knowledge, and the realization of all-round development of morality, intelligence, body, and beauty are very beneficial to the improvement of the intellectual structure of undergraduates, making them an excellent talent for building the motherland and defending the motherland.

In the article "National Defense Education Should Be Included in the General System of Ideological Education," Comrade Jiang Zemin comprehensively and profoundly expounded the fields, principles, and objects of national defense education, and put forward the idea of 
incorporating the content of national defense education in the ideological education system of college students. The main purpose of ideological and political education for college students is to cultivate a socialist successor who is cultural, disciplined, and ethical. Based on this, strengthening the cultivation of college students' national defense awareness can lead them to consciously assume national defense obligations. The cultivation of national defense awareness and ideological and political education are all homogenous in the same book. The two are linked and complementary to each other. Whether it is the purpose of education, the content of education, or the ultimate role of education are all the same. Therefore, national defense education is a new form of ideological and political education in colleges and universities. It is also a useful supplement to the content of ideological and political education.

\section{The Problems in the Cultivation of College Students' National Defense Awareness}

With the increase of enrollment in colleges and universities, the difficulty of ensuring military training for students is increasing, and military training guarantee measures cannot meet current needs. The problem of inadequate military training venues in some colleges and universities is very prominent. A large number of students are crowded in a standard stadium for training, unable to start a team, or even guarantee regular basic training. The contents of military training include not only the basics, but also the formation of defense societies, the development of war games, and the advanced deeds of heroes and model figures. However, the number of institutions that have completed these conditions is minimal, and some students cannot even complete education on national defense awareness. The plan, the actual training time of the students is far from the requirements of the syllabus.

The increase in enrollment in colleges and universities has led to an increase in the number of students, which has made faculty with higher professional militarism and higher levels of ideological and political education in colleges and universities become weaker. The number of actual military full-time teachers is far from enough, and non-professional teachers can only reluctantly perform. The teaching of military theory courses does not have the ability to practice; and non-professional teachers themselves have different theoretical levels, which can not meet the actual classroom needs. Many colleges and universities do not fully understand national defense education, and they lack the energy and conditions for the development of national defense education and military education. Ultimately, the teaching of military theory courses only stays at the theoretical stage, and lacks the driving force for innovation and development. In addition, at present, there are still problems in non-standard and non-uniform military curriculum materials in our country's colleges and universities. The teaching contents are not related to the student's ideological reality. They are not targeted and empty in content, and they can not arouse students' resonance and can not guarantee the teaching effect.

Although the mental development of college students is relatively mature, but they lack sufficient social experience, their daily life is single, and they are less exposed to the society. Therefore, it is difficult to have a deep understanding of all kinds of actions that threaten national security, and there is no personal experience. The importance of national defense education is lacking in the acceptance of national defense courses. In addition, other foreign thoughts will also have an impact on the defense awareness of college students. After China's reform and opening up, both international and domestic development have gradually diluted ideological factors. However, in addition to the inevitability and rationality of this change, the impact of various ideologies on college students will still have a certain impact. Favoring foreign affairs, money worship, hedonism, and so on, the negative impact of these ideologies will weaken the effectiveness of the cultivation of national defense awareness to some extent.

\section{Strategies to Enhance the College Students' National Defense Consciousness}

In view of the problems in the above-mentioned college students' national defense awareness education, it is suggested that improvements be made from the following aspects: 
High-level teacher resources are necessary conditions for ensuring the education of national defense awareness. However, the problem of weak teacher education in national defense education is becoming more and more prominent. Therefore, colleges and universities should take all measures to strengthen the construction of the military professional teachers in national defense in accordance with their actual conditions. Emphasizes the importance of education in national defense awareness. The "inviting in, going out" approach was adopted to innovate the development of the national defense awareness education teacher training model and establish a high-quality national defense education teacher team. First, we must incorporate the national defense education teachers into the school's unified management, introduce graduates from military institutions into full-time teachers, or invite military experts and national defense experts to visit the university as visiting professors, or invite heroic model figures to the school to work part-time. National defense education teachers, etc., to increase the number of teachers, improve the quality of teachers. Secondly, teachers at the school are encouraged to conduct in-service training, plan business training, and continuously improve the in-service teachers' professional abilities so that they can better adapt to the actual needs of national defense education in colleges and universities. Finally, provide more support for university teachers to carry out innovation and scientific research activities, encourage them to constantly explore the laws of contemporary national defense awareness education, and continuously promote the sound development of national defense education in Chinese universities.

First of all, in the community to create a good atmosphere of national defense awareness education, universities and colleges should use the United Nations home government agencies, news dissemination units, etc. to use a variety of effective communication media to educate students on national defense awareness, to promote the fine traditions of patriotism in the whole society, to truly form The social atmosphere conducive to the education of students' national defense awareness is to improve students' importance to national defense education. Second, schools should use the technological advantages of new media to improve the system of national defense education. New media can carry more personalized information resources and improve the direct, in-depth, and vivid nature of national defense education, thus improving the efficiency of national defense education. Finally, combine the students' professional development of national defense education. Combining national defense education with students' professional education and adding professional theoretical knowledge in the course of military theories, this will enable students to have a deeper understanding of their professional relationship with national defense construction and strengthen their national defense awareness. In the senior professional courses, more applications of professional knowledge and technology and scientific research results in national defense science and technology are allowed. Under the premise of conditions, a variety of elective courses are set up to enable students to realize the importance of national defense knowledge through professional learning. To achieve the mutual penetration of national defense knowledge and professional knowledge. In addition, we must pay attention to the organic combination of skills training and scientific and technological activities. For example, organize national defense education festivals, military science and technology festivals, and other activities, link students' scientific and technological works with military technology, and guide and organize students to try out "new weapons" production and inventions to stimulate students' interest in learning.

First of all, when new students enter school, they will hold a military training mobilization meeting to explain the importance of military training from many aspects to the new students and to interpret the relevant provisions and documents of military training so that students can form a correct understanding of military training. It is clear that military training is a strategic national defense task, and it is also The fundamental form of university students fulfilling their national defense obligations is to make students ideologically attach importance to military training and increase their initiative in fulfilling their national defense. During the military training mobilization, a clear military training task should be issued to the students so that the students can clearly define the main purpose and specific requirements of military training, adjust the students' mentality, and make them enter the training state as soon as possible. Military training and mobilization work must 
adhere to the actual situation, combined with the psychological characteristics of contemporary college students, stress practical results, and prevent the flow of forms. At the same time, it is necessary to combine the use of campus radio and other media to mobilize students for military training and mobilization, and create a strong atmosphere of military training on campus. Second, student military training must focus on specific objects and specific requirements. We must continue to enrich training content and training methods to enhance interest. Finally, colleges and universities can organize military training institutions to arrange some practical and practical applications that will enable military training students to master practical knowledge and skills that they will use in their future study and life. Such as fire prevention drills to improve students' ability to respond to sudden natural disasters; explosion-proof anti-terrorism exercises can improve students' ability to respond to sudden social events; anti-theft, self-defense, medical ambulance routine knowledge can improve students' self-defense capabilities. Military training closely related to student life can not only enrich the content of military training, but also increase the effectiveness and practicality of military training, thereby stimulating students' enthusiasm for learning.

\section{Conclusion}

College students are the hope for the future development of our country. They are the builders and successors of the great cause of socialism. They are also the groups with high scientific and cultural qualities in the population structure. Therefore, colleges and universities should examine the issue of the education of students' national defense awareness based on the height of macro-strategies. The current problems in the national defense education in colleges and universities, and with a high degree of responsibility to the education of national defense awareness into the school's overall education plan, increase the proportion of the ideological and political education system, in order to improve students' awareness of national defense. On the other hand, according to the new characteristics of the new era and the new situation, we must strengthen the people's national defense awareness and national security awareness, permeate national defense awareness in every corner of the campus, ensure that the country's main body is safe, and promote social harmony and stability.

\section{Acknowledgment}

Study on the tactics of enhancing students' national defense awareness in the context of military-military integration (Project No. 18JMR66);

Study on the Status Quo of Teaching and Scientific Research of Physical Education Teachers in Local Teachers Colleges and Their Promotion Strategies (Item: SGH16H199)

\section{References}

[1] Hua Aijun. The Deficiency and Countermeasures of the Current Undergraduates' National Defense Awareness[J]. Education Exploration, 2010(2): 139-140.

[2] Xu Songru, Shen Shuyong. Basic Ideas to Enhance the University Students' National Defence Consciousness[J]. Journal of Academic Counselling, 2010(5): 15-17.

[3] Wang Shuping. Investigation and Analysis of the Situation of Contemporary College Students' National Defence Consciousness[J]. Jiangxi Education, 2010(9): 23-24.

[4] Ai Yuejin, Zhu Xu. The significance and countermeasures of enhancing the national defense awareness of "90s" college students[J]. Journal of Ideological \& Theoretical Education, 2009(10): 105-107.

[5] Li Ke. National Defense Education and the Development of College Students' Comprehensive Quality in Colleges and Universities[J]. Journal of Xi'an University of Arts and Science: Social Science Edition, 2012(5): 102-104.

[6] Wang Chuanzhong, Wu Zhongguo. On the Education of National Defence Consciousness and the Cultivation of College Students' National Spirit[J]. National Defense, 2009(4): 44-46. 